\title{
РОЛЬ КОМПЕТЕНТНІСНОГО ПІДХОДУ У РЕАЛІЗАЦІї ЗАВДАНЬ СИСТЕМИ ЯКОСТІ ФАРМАЦЕВТИЧНОЇ ОСВІТИ
}

\author{
А. В. Кайдалова, О. В. Посилкіна
}

Національний фармацевтичний університет, м. Харків

\section{ROLE OF THE COMPETENCE APPROACH IN THE IMPLEMENTATION OF THE OBJECTIVES OF THE QUALITY SYSTEM OF PHARMACEUTICAL EDUCATION}

\author{
A. V. Kaydalova, O.V. Posylkina \\ National University of Pharmacy, Kharkiv
}

\begin{abstract}
У статті розглянуто теоретико-методологічні аспекти компетентнісного підходу. Зроблено аналіз розуміння поняття компетентності та визначено основні компетентності фахівців фармацевтичного профілю. Визначено роль компетентнісного підходу у реалізації завдань системи якості вищої фармацевтичної освіти.

The article considers the theoretical and methodological aspects of a competence approach. Made the analysis of the concept of competence and the main competence pharmaceutical specialists. The role of the competence approach in the implementation of the objectives of the quality system of higher pharmaceutical education.
\end{abstract}

Вступ. Проблема компетентнісного підходу у підготовці майбутніх фахівців фармацевтичної галузі $\epsilon$ предметом досліджень багатьох вітчизняних та зарубіжних науковців. Стан розвитку фармацевтичної галузі в умовах сьогодення зумовлює необхідність підготовки компетентного фахівця фармацевтичного профілю відповідно до вимог сучасності.

Впровадження у практичну фармацію міжнародних стандартів якості обумовлює необхідність побудови системи менеджменту якості і у фармацевтичній освіті. Реформування сучасної системи підготовки фармацевтичних кадрів висвітлює необхідність ії адаптації до положень Болонського процесу, галузевих стандартів, нормативно-правових актів та вимог міжнародних стандартів. Аналізуючи вимоги усіх означених документів, можна визначити основну спільну мету перелічених документів - це підготовка компетентнісних фахівців, які будуть затребувані на ринку праці.

У процесі проведення дослідження використовувалися загальнонаукові теоретичні методи аналізу, а також методи порівняння.

Сформульована актуальність проблеми дозволяє визначити мету дослідження, яка полягає в аналізі поглядів зарубіжних та українських учених на розуміння сутності компетентнісного підходу та визна-

()А. В. Кайдалова, О.В.Посилкіна чення його ролі у побудові системи якості фармацевтичної освіти.

Основна частина. У контексті нашого дослідження встановлено, що ще в середині 80-х років минулого століття вченими Д. Мартенсоном, Б. Оскарсоном та ін. було обгрунтовано і введено у професійну освіту (крім знань, умінь та навичок) нові освітні конструкти - компетенції, компетентності та ключові кваліфікації [16].

За визначенням міжнародних експертів, поняття “компетентність" охоплює задані навички; використання знань і вмінь на робочому місці на рівні встановлених вимог (стандартів); здатність відповідально виконувати обов'язки і досягати запланованих результатів; здатність знаходити рішення у нестандартних ситуаціях; здатність застосовувати знання і вміння у нових умовах виробничої діяльності [8].

Експерти країн ЄС трактують поняття "компетентність" як здатність застосовувати знання та вміння ефективно й творчо в міжособистісних відносинах - ситуаціях, що передбачають взаємодію 3 іншими людьми в соціальному контексті так само, як і в професійних ситуаціях [15].

Аналіз публікацій свідчить про наявність значної кількості досліджень 3 питань впровадження компетентнісного підходу у підготовці фармацевтичних кадрів. Проблеми компетентностей фахівців фарма- 
цевтичної галузі вивчали Л. В. Галій, Г. Т. Глембоцька, В. В. Голубцов, Б. П. Громовик, І. А. Зупанець, Л. Г. Кайдалова, Т. Г. Калинюк, І. В. Міщенко, 3. М. Мнушко, С. М. Мокрянин, Б. Л. Парновський, М. С. Пономаренко, О. В. Раздорська, В. М. Толочко, В. П. Черних та ін.

Так, у роботі [2] зазначається, що компетентностям фахівця в системі охорони здоров'я для випускника медичного навчального закладу притаманні варіативність, взаємозалежність, інтегративність, комулятивність, соціальна та особистісна значущість. Для професійної компетентності характерними є: системність, культуровідповідність, соціальність, міжпредметність, надпредметність, ситуативність, практична орієнтованість і мотивованість використання. Серед ключових компетенцій/компетентностей, на думку автора, велика роль належить соціальним.

Щодо моделі ієрархії компетентностей у фармацевтичній освіті, то автори дослідження [3] виокремлюють такі компетентності: спеціальні, професійні або предметні; загальні (універсальні або загальногалузеві); ключові (політичні та соціальні, міжкультурні, комунікативні, соціально-інформаційні таперсональні).

Наприклад, у монографії [5] професійну компетентність фармацевта або провізора представлено як інтегральну характеристику, яка визначає здатність фахівця вирішувати професійні проблеми і типові професійні завдання, що виникають у реальних ситуаціях його фахової діяльності, з використанням знань і професійного та життєвого досвіду. Автор пропонує такі основні компетентності провізора, як: професійна, ключова, інструментальна, інформаційна, соціальна, психологічна, педагогічна, комунікативна, особистісна та ін.

Моделюванню компетенцій провізора аптеки присвячені дослідження [11, 12], де автори використовують метод групових сесій для визначення компетенцій спеціалістів фармації і визначають такі: диференціювальні і порогові.

У джерелі [14] загальнокультурні компетенції визначаються як складові частини професійної підготовки провізора. Майбутню професійну діяльність автор представляє як гіперкомунікативний процес, що вимагає вирішення питань комунікативних стратегій і міжособових взаємодій.

Автор праці [7] наголошує на тому, що саме орієнтація на компетентнісний підхід у підготовці спеціалістів фармації дозволяє отримати фахівця з широкою базою знань, який володіє не лише конкретними наочними, але й універсальними уміннями і навичками, що дозволяють діяти професійно в життєвих ситу- аціях. До основних складових професійної компетентності фармацевта, відповідно, віднесено: соціальноправові, персональні та спеціальні.

У роботі [9] автори виділяють у підготовці фармацевтичних кадрів не тільки спеціальні (фахові) компетентності, але й загальні, які мають бути покладені в основу новоутворення державних стандартів вищої освіти.

У дослідженні [6] наголошується, що “професійна компетентність фармацевтичних працівників" являє собою сукупність знань, здібностей, якостей і властивостей особи, необхідних для успішної діяльності в даній сфері, і $є$ одним з основних етапів становлення провізора.

Вивчення досвіду розробки моделі сучасного провізора і фармацевта на основі компетентнісного підходу в Росії, зокрема в у Курському державному медичному університеті та в Інституті інформації та інформаційних технологій Росздоровнагляду, показали, що сьогодні фармацевти досить часто виконують обов'язки провізорів. Групою експертів було визначено орієнтовний пакет компетентностей як для фармацевта, так і для провізора, який було покладено в основу розробки нових освітніх стандартів з підготовки провізорів у Росії [4].

У дослідженнях щодо професійної компетентності фармацевтичних кадрів автор статті [1] піднімає проблеми стосовно нових вимог до підготовки провізорів, серед яких уміння поєднувати ринкові та соціальні принципи роботи у фармацевтичних організаціях.

У Федеральному державному освітньому стандарті зі спеціальності “Фармація” (Росія) згруповано 15 загальнокультурних та 48 професійних компетенцій, які являють собою в сукупності єдину парадигму та демонструють механізм взаємодії всіх дисциплін, націлений на кінцевий результат [13].

У роботі [10] при дослідженні питання компетентностей фахівців фармацевтичного профілю робиться акцент на професійних, при цьому виокремлюються функціональні обов'язки провізора та фармацевта.

Отже, проведений аналіз дозволив зробити висновок, що у авторів $\epsilon$ розбіжності визначень і трактування понять "компетентності" i “компетенції". А отже, під компетенцією слід розуміти здатність i готовність фахівця якісно виконувати певні функціональні завдання професійної діяльності, а компетентність - це професійні знання, уміння, навички та досвід людини в рамках конкретної діяльності, зокрема у фармацевтичній галузі.

Наступним кроком нашого дослідження став порівняльний аналіз переліку компетентностей фахівців 


\section{ВДОСКОНАЛЕННЯ ВИЩОЇ МЕДИЧНОЇ ОСВІТИ}

фармації, пропонованих різними авторами з метою виявлення їх пріоритетності. Проведений аналіз дозволив дійти висновку, що більшість дослідників виокремлює та обгрунтовує такі компетентності, як: професійні та ключові, а диференціювальні, інформаційні, педагогічні, порогові, предметні, психологічні, системні та соціальні компетентності виділяють окремі науковці, що представлено за допомогою діаграми (рис. 1). Діаграма побудована на аналізі кількості авторів досліджень та переліку виділених ними компетентностей.
Із діаграми видно, що професійні компетентності виділяються у восьми із дев'яти досліджуваних публікаціях, це свідчить про те, що всі автори надають перевагу саме професіоналізму фахівців фармації. Далі 4 автори виділяють ключові компетентності, 2 автори виділяють загальні, спеціальні, комунікативні, міжособистісні та інструментальні. Такі компетентності, як диференціювальні, інформаційні, порогові, педагогічні, предметні, системні та соціальні, не є загальноприйнятими і їх виділяють окремі автори.

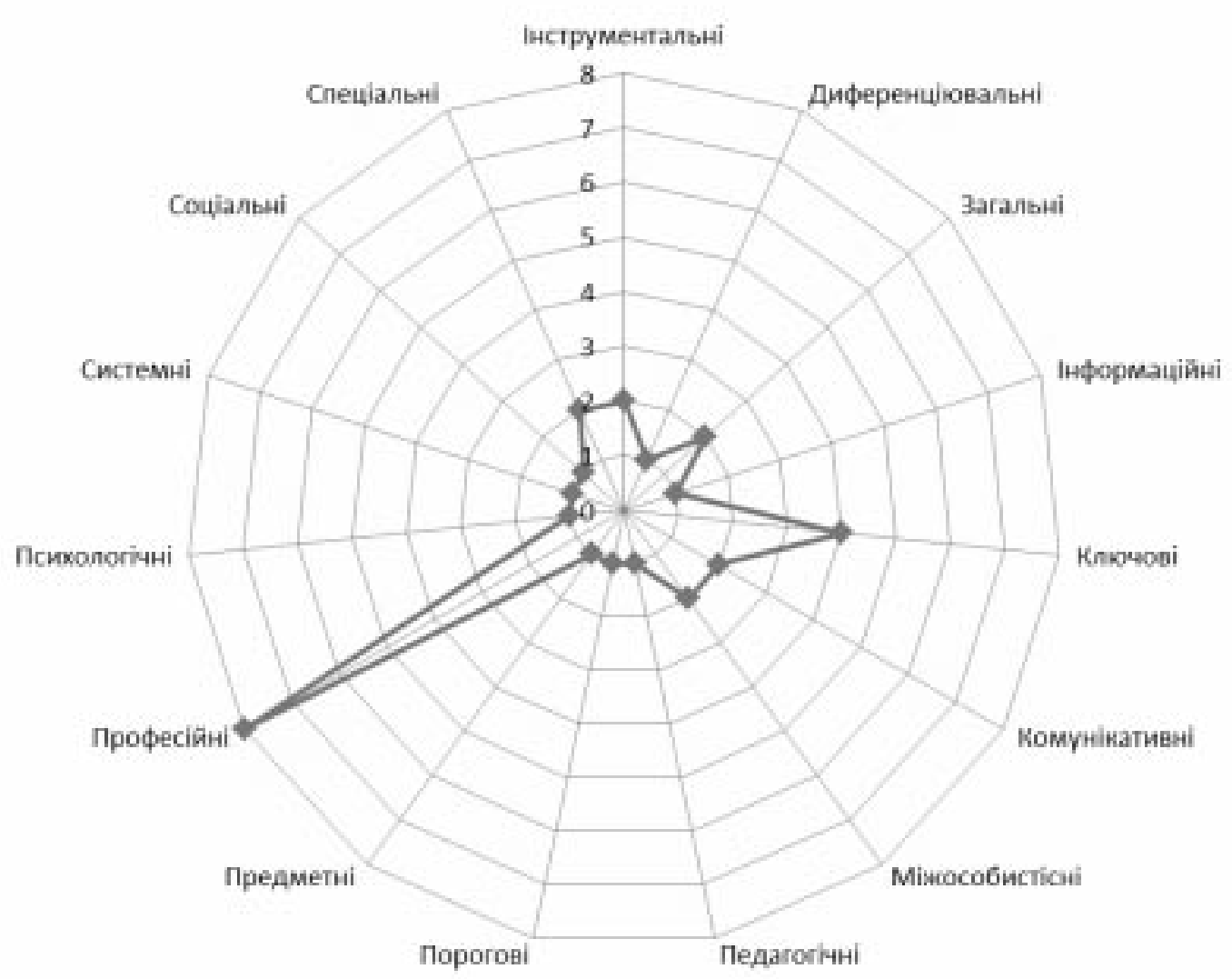

Рис. 1. Діаграма визначених компетентностей фахівців фармації, запропонованих різними науковцями.

Основним завданням системи якості вищої фармацевтичної освіти є вдосконалення освітніх стандартів, навчальних програм та поліпшення якості надання освітніх послуг з метою задоволення потреб суспільства та підготовки фахівців, що відповідають вимогам ринку праці. Упровадження системи менеджменту якості у фармацевтичній освіті вимагає в першу чергу розробки системи необхідних документів, навчально-методичного забезпечення, матеріально-технічної бази, а також наявного кваліфікованого професорсько-викладацького персоналу y BH3.
Висновки. Узагальнення результатів проведеного дослідження дозволило дійти висновку про наявність суперечностей у визначеннях компетентностей фармацевтичних фахівців та необхідності подальшого дослідження у цьому напрямі. Враховуючи необхідність розробки та впровадження системи менеджменту якості у ВНЗ та актуалізацію компетентнісного підходу у підготовці фахівців фармації, визначено взаємозв' язок між ними. 


\section{Література}

1. Глембоцкая Г. Т. Многогранность, специфичность и ответственность работы провизора-специалиста нового тысячелетия / Г. Т. Глембоцкая // Вестник ВГУ. Серия: Химия. Биология. Фармация. -2004. -№2.-С. 175-178.

2. Голубцов В. В. Компетентностный подход как основа качества обучения и воспитания в медицинском университете / В. В. Голубцов // Сборник материалов учебно-методической конференции. - Курск : КГМУ, 2007.-С. 9-10.

3. Громовик Б. П. Перспективи нових навчальних технологій у фармацевтичній освіті / Б. П. Громовик, С. М. Мокрянин // Фармацевтичний журнал. -2008. -№2.-С. 13-21.

4. Денисова Н. Г. Развитие компетентностного похода в последипломном обучении фармацевтических специалистов на основе исследования образовательных потребностей персонала аптечных учреждений / Н. Г. Денисова, И. П. Комиссинская // Сборник материалов учебно-методической конференции. - Курск : КГМУ, 2007.-С. 20-23.

5. Кайдалова Л. Г. Професійна підготовка фахівців фармацевтичного профілю у вищих навчальних закладах / Л. Г. Кайдалова. -Х. : НФаУ, 2010 .-364 с.

6. Лузик О. В. Изучение профессиональной компетентности провизора как фактора мотивации к успеху [Электронный ресурс] / О. В. Лузик. - Режим доступа : http:// inf.docdat.com/docs/481/index-132702.html

7. Миняева О. А. Механизм формирования и этапы реализации компетенций специалистов в области фармации / О. А. Миняева // Актуальные задачи педагогики : материалы международной научной конференции. - Чита : Издательство Молодой ученый, 2011. - С. 220-222.

8. Державні стандарти професійної професійної освіти: теорія та методика/ за ред. Н. Г. Ничкало.-Хмельницький : ТУП, 2002.-334 c.

9. Загричук Г. Я. Підготовка фахівців у вищих навчальних закладах України в сучасних умовах на основі компетент- нісного підходу / Г. Я. Загричук, В. П. Марценюк, І. Р. Мисула // Медична освіта. - № 1.-2013. - С. 8-11.

10. Солонинина А. В. О профессиональных компетенциях специалистов фармацевтического профиля: разграничение функциональных обязанностей провизора и фармацевта / А. В. Солонинина, Н. Ю. Порсева, И. В. Крупнова // Менеджмент качества в сфере здравоохранения и социального развития. -2011. - № 1(7). - С. 143-149.

11. Толочко В. М. Наукове обгрунтування та розробка моделей компетенцій спеціалістів фармації : методичні рекомендації / В. М. Толочко. -К., 2009.-23 с.

12. Толочко В. М. Наукове обгрунтування зарубіжного досвіду визначення компетенцій персоналу / В. М. Толочко, Л. В. Галій // Фармацевтичний журнал. -2009. - № 2. C. $40-45$.

13. Формирование компетенций студентов в системе профессиональной подготовки в фармацевтическом вузе / И. Л. Андреева, А. Н. Пивоваров, Т. Б. Уткина [и др.] // Фармація. - 2010. - № 1. - С. 53-56.

14. Шульженко В. И. Общекультурные компетенции как составная часть профессиональной подготовки провизора [Электронный ресурс] / В. И. Шульженко // Вестник ПГЛУ.-2011.-№ 1.-Режим доступа : http://www.pglu.ru/ vestnik/2011/1/ShulzhenkoIpdf.

15. Kogan I. Comparative analysis of higher education systems in central and Eastern Europe. Ottawa, Canada. October 2000 [Электронный ресурс]. - Режим доступу : http://www.mzes.uni-mannheim.de/d7/en/profiles/irenakogan.

16. Mertens D. Schlueselgualifikation. Thesen zur Schuiung for eine Moderne Geseltschaft // Verlag W. Kohlhammer / Einfohrung in die Berufspedagogik. - Stuttgart, 1991.-S. 14.

Отримано 29.04.14 